\title{
Aphids of the genus Diuraphis caught by Johnson suction trap in Poznań, Poland
}

\author{
Przemysław Strażyński*, Maria Ruszkowska, Arleta Krówczyńska
}

Department of Entomology, Institute of Plant Protection - National Research Institute, Władysława Węgorka 20, 60-318 Poznań

Received: September 6, 2016

Accepted: November 13, 2016

\begin{abstract}
In 1973-2011 in Poznań, aphid catches were carried out using Johnson's suction trap. Since then the suction trap located at the Institute of Plant Protection - National Research Institute in Poznań has continuously recorded the daily and seasonal dynamics of aphid flights. The collected results has been used to establish one of the largest databases of this type in Europe. The data also allow tracking changes in aphid biodiversity under the changing climatic conditions. Three aphid species of Diuraphis spp. were identified: D. muehlei (Börner, 1950) - in 1974, D. bromicola (Hille Ris Lambers, 1959) - in 1988, D. noxia (Kurdjumov, 1913) - in 2003 as a result of systematic and long-term aphid collections. The occurrence of $D$. noxia presents a particular risk to cereal crops in Poland. This expansive aphid species that originates from Asia and the Mediterranean is a vector of Barley yellow dwarf viruses (BYDV), and has become one of the most important pest of wheat and barley in the world. Changes in climatic conditions that have been observed in recent years in Poland such as hot summer, long and warm autumn, mild winter seem to be optimal for occurrence and development of aphid species from warmer parts of Europe.
\end{abstract}

Key words: aphids, Diuraphis spp., Johnson suction trap

\section{Introduction}

Aphid catches using Johnson suction trap were carried out from 1973 to 2011 (Ruszkowska 1987; Strażyński et al. 2011). During the same time period, the suction trap was located at the Institute of Plant Protection - National Research Institute in Poznan that incessantly registered the daily and seasonal dynamics of aphid flights. The collected data have been used to establish one of the largest databases of this kind in Europe. The suction trap catches also allow following changes in aphid biodiversity in the changing climate. Many factors, especially temperature, have an impact on aphid development and their geographical distribution. Temperature directly influences the insect's body as well as through host plant phenology (Ruszkowska 2007). High specialization of aphids, which had been formed over the evolution allows for quicker adaptation respond to changing environmental conditions. Such a unique ecological flexibility lets to perceive aphids as bio-indicators of all types of environmental changes, including climate warming indicators (Harrington et al. 1995; Ruszkowska 2007). Mainly due to climate changes, but also changes in crop technologies or free trade in plant material, new insect species emerge, including new aphid species, which find favourable conditions for their growth in new locations. Detection of a new species in a suction trap does not mean that this particular species occurs on plants as it might be due to passive aphid flights, along with the air flow, where they constitute air plankton, and may take place for up to 2,000 km. Yet Johnson's suction trap is an efficient tool in the assessment of aphid migrations as well as the warning of the appearance of alien and invasive species. However, detection of a given species in the suction trap does not prove an occurrence of particular species on plants that should be confirmed by other means (Teulon and Scott 2006).

\section{Materials and Methods}

Aphids were caught during the years 1973-2011 by Johnson suction trap at the height of $12.2 \mathrm{~m}$, with filters $0.75 \mathrm{~m}^{3}$ of air per second (Macaulay et al. 1988). The trap was located in Poznań, Wielkopolska region, Poland, and the attempts of the catches were taken everyday. Out of all the species that were caught, special attention was paid to the species of the genus Diuraphis. The species of aphids were identified based on the aphids species on the slides and using the available literature (Múller 1964; Stacherska 1975; Blackman and Eastop 2000).

\section{Results and Conclusions}

As a result of systematic and long term aphid catches were found three species of Diuraphis genus: Diuraphis muehlei, D. bromicola, and D. noxia. 


\section{Diuraphis muehlei (Börner, 1950)}

This species was detected and registered for the first time in Poland in 1974 at the seed plantation of Timothy-grass (Phleum pratense L.) when individuals were feeding among undeveloped yet twisted leaves (Stacherska 1975). The species presence (one individual) was confirmed the same year in the suction trap catches (20 July 1974). During the entire period of suction trap catches this species was caught occasionally. Diuraphis muehlei is a monophagous aphid species, which develops holocyclically causing damage to Timothy-grass seed plantations in Europe. This species on Timothy-grass causes physiological disturbance resulting in dying out shoots (white spot leaves). In Europe the species is also registered on water foxtail (Alopecorus geniculatus L.) and proso millet (Panicum miliaceum L.) (Holman 2009).

Morphological characters: oval body, length 1.3$2.0 \mathrm{~mm}$, yellow with wax coating. Dark antennae, $1 / 3^{1 / 2}$ of body length. Short siphunculi $(0.05 \mathrm{~mm})$ in the shape of a cut cone, almost as long as wide at the base. A characteristic supracaudal appendix on the eighth segment of the abdomen. Tongue-like cauda. In wingless morphs the head is almost pigment-less, and in winged ones the head and abdomen are dark brown (Müller 1964).

\section{Diuraphis bromicola (Hille Ris Lambers, 1959)}

The presence of this species was recorded for the first time on plants in 1967, on the collapsed young leaf of Bromus mollis L. (Achremowicz 1972) and in 1988 (23 July 1988) one individual was caught in the Johnson's suction trap. The species settles Bromeae (Bromus sp.) (Holman 2009).

Morphological characters: longitudinal, oval body, 1.8-2.0 mm length, dark green with a grey wax coating. Antennae are $2 / 5$ of body length; cauda is only slightly longer than wide at the base (Müller 1964).

\section{Diuraphis noxia (Kurdjumov, 1913)}

This species (one individual) was caught for the first time in the suction trap in Poznań in 2003 (16 August 2003). The specimens of this species (adult and larvae - a total of 14 aphids) were also found in the autumn on winter cereals in the Lubuskie province, near Łagów (4 October 2003). It has not been found thereafter in Poland on plants and in suction trap. Diuraphis noxia is a dangerous cereal pest, classified as alien and invasive - as an expansive virus vector in North America, Africa, Asia and Western Europe, as well as the Czech Republic, Slovakia and southwestern Ukraine (EPPO 2016). In Europe it has been registered on grasses of the following genera: Agropyron spp., Avena spp., Brachypodium spp., Bromus spp., Fastuca spp., Hordeum spp., Lolium spp., Secale spp. i Triticum spp. (Holman 2009). It is caught by suction trap every year in great numbers in Czech Republic and in Germany. This information was enclosed in the list of aphids caught by suction traps throughout Europe (Grant number EVK21999-00151 EXAMINE) and confirmed personally by the suction trap operators.
The best developmental conditions for this species is $18-21^{\circ} \mathrm{C}$ on wheat in growth stages from jointing to heading $D$. noxia develops faster, lives longer and has higher fecundity on wheat plants than on rye (Behle and Michels 1990). Diuraphis noxia has been mainly recorded on winter cereal crops from which it migrates into maize and then it returns to young winter cereal crops on which females lay 8-10 eggs on the top side of leaves, along the major veins. One hundred percent of eggs die in temperature of below $30^{\circ} \mathrm{C}$ (Armstrong et al. 1992; Butts 1992).

Morphological characters: spindly body, yellowgreen, with wax coating, 1.5-2.5 mm, 6-segment-long antennae, $1 / 3$ of body length, darker at the ends, cauda is long (Blackman and Eastop 2000).

\section{The threat to cereal crops in Poland}

Considering few described above species the occurrence of $D$. noxia presents a particular threat to cereal crops in Poland. This expansive aphid species originating from Asia and the Mediterranean has become one of the most important wheat and barley pest in the world causing harvest losses up to several hundred million dollars per year. In Europe D. noxia has been registered in Macedonia and Hungary in 1989 from where it quickly spread to the Carpathians region (Basky and Eastop 1991; Starý et al. 2003). In 2000 in Slovakia it received a status of the most important pest of summer barley (Lukáš et al. 2001). It is reported as a virus vector of Barley strip mosaic virus (BSMV), Barley yellow dwarf virus (BYDV) and Brome mosaic virus (BMV) (Damsteegt et al. 1992).

\section{The impact of weather conditions on the occurrence of Diuraphis spp.}

Weather conditions such as very hot summers, long and warm autumn and mild winters, which have been observed in recent years in Poland seem to be favouring occurrence and development of aphid species from warmer parts of Europe. The fact that these species were detected in the suction trap implies that the natural barrier, which is constituted by northern range of the Carpathians on the way of aphid migration, is insufficient. In the nearest future climate changes might cause appearance of new aphid species on various crops and occurrence of Crypturaphis grassi (Silvestri, 1935) is already an example of these changes.

\section{References}

Achremowicz J. 1972. Mszyce (Homoptera, Aphidodea) Niziny Wielkopolsko-Kujawskiej II [Aphids (Homoptera, Aphidodea) on Wielkopolsko-Kujawska Lowland]. Fragmenta Faunistica XVIII 19: 361-392.

Armstrong S., Peairs F., Nielsen D., Roberts E., Holtzer T., Stushnoff C. 1992. The overwintering biology of Diuraphis noxia on the Northeastern Plains of Colorado. Great Plains Agriculture Council Publishing 142: 211-212.

Basky Z., Eastop V.F. 1991. Diuraphis noxia and other cereal aphids in Hungary. Journal of Aphidology 5: 1-8. 
Behle R.W., Michels G.J. 1990. Russian wheat aphid development, reproduction and survival on wheat and rye grown in four host-plant media. Southwestern Entomologist 15 (2): 109-121.

Blackman R.L., Eastop V.F. 2000. Aphids on the World's Crops. An Identification and Information Guide. 2nd ed. John Wiley \& Sons, Ltd., 476 pp.

Butts R.A. 1992. Cold hardiness and it relationship to overwintering of the Russian wheat aphid (Homoptera: Aphididae) in southern Alberta. Journal of Economic Entomology 84 (4): 1140-1145.

Damsteegt V.D., Gildow F.E., Hewings A.D., Caroll T.W. 1992. A clone of the Russian wheat aphid (Diuraphis noxia) as a vector of the barley yellow dwarf, barley strip mosaic and brome mosaic viruses. Plant Disease 76: 1155-1160.

EPPO (European Plant Protection Organization). 2016. Available on: https://gd.eppo.int/taxon/BRAYNO/distribution [Accessed: November 7, 2016]

Harrington R., Bale I.S., Tatchel G.M. 1995. Aphids in a changing climate. p. 126-158. In: "Insects in a Changing Environment" (R. Harrington, N.E. Stork, eds.). Academic Press, London, UK, $535 \mathrm{pp}$.

Holman J. 2009. Host Plant Catalog of Aphids. Palearctic Region. Springer Science + Business Media B.V., 1216 pp.

Lukáš J., Tóth P., Vráblová M., Lukášová Z., Cagáň L. 2001. First records of Diuraphis noxia (Homoptera, Aphididae) from Slovakia. Biologia, Bratislava 56 (1): 1.

Macaulay E.D.M., Tatchell G.M., Taylor L.R. 1988. The Rothamsted insect survey '12-metre' suction trap. Bulletin of Entomological Research 78 (1): 121-128.

Müller F.P. 1964. Merkmale der in Mitteleuropa an Gramineen lebenden Blattläuse (Homoptera: Aphididae) [Charac- teristics of the aphids (Homoptera: Aphididae) living on Gramineae in the Central Europe]. Wissenschaftliche Zeitschrift der Universität Rostock. Mathematisch-Naturwissenschaft Reihe 13 (2-3): 269-278.

Ruszkowska M. 1987. Population dynamics of cereal aphids in Poland from 1973 to 1984. p. 209-218. In: "Population Structure, Genetics and Taxonomy of Aphids and Thysanoptera" (J. Holman, J. Pelikan, A.F.G. Dixon, L. Weismann, eds.). Publishing House of The Slovak Academy of Sciences, Bratislava, 542 pp.

Ruszkowska M. 2007. Across the transformation life cycle of Rhopalosiphum padi (L.) (Homoptera: Aphidoidea): coevolution with temperature. Rozprawy Naukowe Instytutu Ochony Roślin, Z. 15, 60 pp.

Stacherska B. 1975. Diuraphis muhlei Börn. - nowy szkodnik upraw nasiennych tymotki w Polsce [Diuraphis muhlei Börn. a new pest of seed cultivations of timothy in Poland]. Prace Naukowe Instytutu Ochrony Roślin 15 (2): 187-190.

Starý P., Basky Z., Tanigoshi L.K., Tomanović Z. 2003. Distribution and history of Russian wheat aphid, Diuraphis noxia (Kurdj.) in the Carpathian basin (Hom., Aphididae). Journal of Pest Science 76 (1): 17-21.

Strażyński P., Ruszkowska M., Węgorek P. 2011. Dynamika lotów mszyc w latach 2008-2010 najliczniej odławianych w Poznaniu aspiratorem Johnsona [Flights dynamics of aphids caught numerously by Johnson's suction trap in Poznań in 2008-2010]. Progress in Plant Protection/Postępy w Ochronie Roślin 51 (1): 213-216.

Teulon D.A.J., Scott I.A.W. 2006. The use of suction traps for detection of unwanted invasive insects and other invertebrates. New Zealand Plant Protection 59: 125-131. 